Anja Kervanto Nevanlinna

\title{
UNIVERSITIES IN URBAN HISTORY: THE UNIVERSITY OF HELSINKI AS A LANDSCAPE OF DIALOGUE
}

\section{ENLIGHTENMENT AS A PROJECT OF DIALOGUE}

In urban history, universities have transformed cities, and cities have transformed universities. Cities have grown on the basis of the university community. For their development, cities have needed the knowledge and understanding produced at the university by its scholars, students and academic traditions. The idea of the university sometimes seems to have been intertwined with the name of the city: just think about Oxford, Bologna, Heidelberg or Tartu. From the perspective of the history of cities perceived as built milieus, the connection seems to be even stronger. For centuries in many cities, university buildings were located in the center of the city and the center of power. In Helsinki from the 1820s until today, the Senate building and its national political power institution faces the University and its academic and scientific elite.

The project of Enlightenment was essentially about taking ideas developed abstractly in books and applying them to the 
real world to change it. Different interpretations of reality were to be set against each other in discourse. In this sense, the spirit of Enlightenment was not one of consensus but of debate. ${ }^{1}$ The European humanistic ideal of the university has involved engagement in dialogue with the context of the university, the society of which it was part. Furthermore, the ideal also has been connected to the university landscape, its visual and physical urban surroundings. In different times, the relationship of the university institution to the larger society has varied, and the participants in the dialogues have also changed. The urban history of the University of Helsinki provides an illustrative example of the transformations of university dialogues.

The origin of the University of Helsinki is in another city, Turku. Queen Christina of Sweden had founded the Academia Åboensis the beginnings of the present University of Helsinki - at Turku in 1640, just a few years after the founding of the Academia Gustaviana at Tartu. Turku was then in all respects the most important town of the eastern provinces of Sweden, the area now defined as Finland. Within the Kingdom of Sweden, Turku was the second major city after Stockholm. In the center of the town was the Cathedral, its oldest parts from the $14^{\text {th }}$ century. The Main Building of the Academy of Turku was constructed in 1800-1815.

\section{POLITICAL NEGOTIATIONS}

In the beginning of the $19^{\text {th }}$ century, Europe went through massive political changes. For the history of the university, two processes were particularly significant. The first concerned imperial politics. As a consequence of the Napoleonic wars, Sweden ceded its eastern provinces to Russia which made them - together with a Russian province - into the Grand Duchy of Finland in 1809. Political historians have seen this as the origin of the eventually emerging nation-state. The second process was related to internal affairs within the Russian Empire. In 1812, Emperor Alexander I of Russia raised the small trade town Helsinki into the capital of the Grand Duchy. Turku lost its leading position.

1 Tzvetan Todorov, L'Esprit des Lumières (Paris: Robert Laffont, 2006), 9-10. 
The political program of the Emperor was to establish Russia as a European power. Helsinki became a demonstration of this. Helsinki had suffered from an extensive fire after the war. After it was made capital, Helsinki and particularly its center was reconstructed with a government-funded building program that involved the erection of buildings for the new institutions. The classical architecture of these institutions was used as a symbol of the European cultural values in the past and in the present. Like in many other cities at this time, the center of Helsinki contained clear references to classicism and Antiquity which many Europeans perceived as the roots of European civilization.

The third process that influenced the history of the University of Helsinki came later. In 1827, an extensive fire destroyed large parts of Turku, damaging not only the buildings but essentially the activities of the town, including those of the Academy. The University Library lost almost all its valuable books, with only those books saved that had been given out for loans. In consequence of the catastrophe, the Emperor moved the Academy to Helsinki in 1828 and renamed it as the Imperial Alexander University of Finland.

For the reconstruction of Helsinki begun in the 1810s, a new gridiron plan had been imposed on the hilly and rocky topography. In a true Cartesian manner, it demonstrated the power of rational thinking over the caprices of nature. Carl Ludvig Engel who had been born and educated at Berlin was recruited as architect for the reconstruction project. He had left Prussia because of the difficult situation during Napoleon's conquest and had worked in Tallinn and in Turku. His commission from the Emperor was very clear: Helsinki was to be built as a symbol of the event that a new political entity, Finland, had been born. This was the Emperor's message to both the Finnish people and the rest of Europe. ${ }^{2}$

The Senate Square and its architecture must be perceived as a representation of not only St Petersburg and its architectural landscape, but also of the Emperor and his Empire. ${ }^{3}$ It made the presence of the Emperor and his power visible in the administrative

2 Matti Klinge, Bernadotten ja Leninin välissä. Tutkielmia kansallisista aiheista (Between Bernadotte and Lenin. Essays on national topics) (Helsinki: WSOY, 1975), 92.

3 Cf. Louis Marin, Le Portrait du roi (Paris: Les Éditions de Minuit, 1981), 9-11, 221-235. 
core of the capital of the Grand Duchy. Through the visual effect, the architecture of the Senate Square made the power of the Emperor over the people of Finland omnipotent and legitime.

The Empire style, also defined as Neoclassicism, was Engel's and the Emperor's choice for the architecture of the major institutional buildings in Helsinki. Visitors from Russia saw the Senate Square as a fragment of St Petersburg. ${ }^{4}$ The most important government building was the Senate Building on the eastern side of the neoclassical square. Originally, the site facing it, on the western side of the square, had been reserved for the Palace of the Emperor. After the Turku fire, the Emperor donated the site to be used for the construction of the University. ${ }^{5}$ The Aula Magna of the University was placed on the same symmetry axis as the Senate Council Chamber in the Senate Building, an axis visually joining political and intellectual power.

The Senate Square was the symbol of Finland, the Grand Duchy of Russia, and was encircled by the three main institutions: the Senate, the University and the [Lutheran] Church. The fourth side, on the south, was the civil society, the urban bourgeoisie of the capital. The newly opened long main street of Helsinki brought people arriving from the north directly to the heart of city at the Senate Square. It was called Unioninkatu (Union street) to celebrate the union between Russia and Finland. Approaching the Senate Square, one would pass the Military Hospital and the University Library before arriving in front of the University on the western side of the square. The University Observatory on a hill at a distance marked the southern end of the street. ${ }^{6}$

Even with the limited resources of Finland at this time, the University buildings - the Main Building, the Library and the Observatory - represented a level that few European universities surpassed. Emperor Alexander I had doubled the funding for the University already in 1811, which also demonstrated its significance for the ruler. After 1809, the ideological frame of the Finnish elite

4 The Neoclassicism of the Senate Square has sometimes been defined as the St Petersburg version of the Empire style.

5 The Senate Building was completed in 1822, the University (Main Building) in 1832.

6 The Church (today, Cathedral) was completed in 1852. The Military Hospital had been completed in 1823, the Observatory in 1834 and the University Library in 1840. 
was Enlightenment rationalism and German humanism. It was a continuation of the traditions of Empress Catharine of Russia, and strengthened contacts with St Petersburg and its Academy of Sciences. In Sweden in contrast, this was a period of rising romanticism. ${ }^{7}$ Connections to Enlightenment ideals were stronger in Finland than in Sweden.

The Imperial Alexander University was located in the capital of the Grand Duchy, which emphasized its significance in society and also its integration with the general politics of the state. In Helsinki, the University was not about a peaceful Arcadia with its own academic pursuits. In this it differed from, for example, the universities of Sweden which were not located in the capital and were more detached from its political activities. ${ }^{8}$ The dialogue of the University in Helsinki was with the Empire and its political elite, indicated not only in the activities and role of the University in society but also in their physical representation, the urban and architectural landscape. At the neoclassical heart of Helsinki, the University Main Building formed a symmetric pair with the Senate Building to express the idea of the unity of the ideals of the state and the university.

Until the 1870s, the major institutional buildings such as the University and the University Library, the Church and the Senate Building dominated the skyline and vistas of Helsinki. The neoclassical heart of Helsinki with its monuments for state institutions was the visual focus of the city, surrounded by smaller residential blocks. With the construction of the railway in the $1860 \mathrm{~s}$ to inner Finland and in 1870 to St Petersburg, the industrialization and urbanization of the country gained impetus. It entailed the rapid development of both Helsinki and the University. The urban scale increased, and the new, more prominent commercial buildings gradually began to dominate the townscape.

7 Klinge, Bernadotten ja Leninin välissä, 91-101.

8 Ibidem, 92-93. 


\section{COMMUNICATION AMONG SPECIALISTS}

The latter part of the $19^{\text {th }}$ century and early $20^{\text {th }}$ century was a time of technological progress and rapid economic growth in Europe. For industrial development, the role of science and universities was crucial. Expansion into new fields of study and research methods necessitated new built forms such as scientific laboratories. ${ }^{9}$ The establishment of universities of technology to develop innovations based on science coincided with the demands of the changing society. The formation of new modern disciplines and increasingly specialized fields of study were based on models adapted from leading European universities. Academic communities emphasized their need for separate institutes with their own buildings planned for specific demands. For universities this involved an extensive building program.

At the University of Helsinki, the laboratories for the Institute of Chemistry were constructed in 1869 in the immediate vicinity of the Senate Square and the oldest University buildings. By the turn of the century, requirements for space had increased, and a new institute area was located on a prominent site at the northern edge of the center of Helsinki. New scientific laboratories were constructed for the Institute of Physiology and the Institute of Physics in the first decade of the twentieth century, and for the Institute of Anatomy in the 1920s, all designed by leading architects of the country. ${ }^{10}$

In the first decades of the twentieth century, Helsinki expanded to the north and northeast. An area for municipal hospitals for epidemic diseases and tuberculosis was located at the northern boundary of the city. Nearby at Meilahti, the first plans were prepared in 1914 for new buildings for the University Hospital, inspiring suggestions around the time of the Independence of Finland (1917) to move the whole University there. ${ }^{11}$ This was not

9 Eric Hobsbawm, The Age of Capital 1848-1875 (London: Abacus, 1977), 56-60, 298-316; Päiviö Tommila, 'Suomalaisen tieteen voimakkaan kasvun kausi' ('The Strong Period of Growth in Finnish Science'), Suomen tieteen historia, vol.4: Tieteen ja tutkimuksen yleinen historia 1880-luvulta lähtien, ed. by Päiviö Tommila (Helsinki: WSOY, 2002), 52-57.

10 Tommila, ibidem.

11 Rainer Knapas, 'Rakennettu ja rakentamaton yliopisto' ('The Built and Unbuilt University'), Helsingin yliopisto 1640-1990, vol. 3: Helsingin yliopisto 1917-1990, ed. by Matti Klinge, Rainer Knapas, Anto Leikola, John Strömberg (Helsinki: Otava, 1990), 588-591. 
realized, and the Meilahti area began to be developed as part of the Faculty of Medicine. In the early 1930s, the first major institution, the functionalistic University Hospital for Women, was established there. The architectural idea of specialized institutions had begun to evolve into the urban concept of functionally specialized institutional areas.

After World War II, the idea of specialized experts and buildings that were tailored according to the specific needs of the discipline gained more force. United States provided modern models for University architecture. They strongly influenced the architects: Alvar Aalto in planning the Helsinki University of Technology and Veli Paatela in his campus for the Faculty of Agriculture and Forestry of the University of Helsinki. Both were large areas located at the edge of the built city, with a number of buildings erected for different purposes. During World War II, Paatela had worked with Aalto at the Massachusetts Institute of Technology in the United States. The plan of the compound of the Faculty of Agriculture and Forestry at Viikki was described through the idea of the 'village' of the researchers and students, a peaceful realm far from the disturbances of the city center. ${ }^{12}$ In addition to the auditoriums, seminar rooms, laboratories and libraries, the building program also included residential units, club houses with restaurants and sports facilities, all to ensure that there would be no need to leave the campus.

The notion of the campus, separate from the city, as the ideal form for a university was perceived worldwide in the latter part of the $20^{\text {th }}$ century as necessary for the modernization of the university activities and spaces. Old buildings were seen as hindrances in the attempt to achieve the increasingly specified scientific goals. As an ideology, however, the concept of the campus had roots in Enlightenment ideals, illustrated in Thomas Jefferson's plan for the 'Academical Village' that evolved into the University of Virginia. The growth of towns around early universities such as Oxford also reflects the notion of the university community as the core of intellectual institutionalization.

12 Anja Kervanto Nevanlinna, 'Voimat jotka rakensivat Helsinkiä 1945-2010' ('The Forces that Built Helsinki 1945-2010'), Helsingin historia vuodesta 1945, vol. 3 (Helsinki: City of Helsinki \& Otava, 2012), 170-172. 
The campus ideology was adopted into the University of Helsinki as its main model of organization in the 1970s. In addition to the Medicine campus at Meilahti and the Agriculture and Forestry campus at Viikki, a third campus for the hard sciences such as mathematics, chemistry and physics was planned at Kumpula. The high tower block of the University Hospital at Meilahti became the dominant of the landscape; its aesthetics, however, did not represent traditional monumentality, but architectural modernism.

For the academics of the humanities and social sciences, in contrast, location in the center of Helsinki was important. Although the models of the social sciences were adopted from the United States, the notion of a Humanities campus far from the center did not appeal. The architectural ideas applied in the modern, late 1950s extension of the Main Building of University on a neighboring site were about standardization, new element-based building technology and efficiency, also in terms of the aesthetics of the building. The concept was firmly anti-monumental. The facades of the building could have easily been those of an office building, a factory, a school or a residential building. On a symbolic level, the architecture implied that the university was open to all its citizens: it was an institution in the service of the society, for civilizing it and making it a better place to live in. ${ }^{13}$ More generally, the institution buildings for the modern disciplines can be seen as concretizations of the trust of the society in the capacity of scientific and academic research to further progress.

From the 1880 s to the $1980 \mathrm{~s}$, then, in the university the specialization of the disciplines increased. In each field of study, the national and international disciplinary networks were important, at times more important than contacts with other disciplines in the same university. ${ }^{14}$ The dialogue of the university was less with the government institutions, as it had been in the early decades of the university, and increasingly with international colleagues within each discipline. This also influenced the evolving university landscape. The new laboratories were equipped with instruments

13 Kervanto Nevanlinna, 'Voimat jotka rakensivat Helsinkiä 1945-2010', 71-73.

14 Eric Hobsbawm, The Age of Empire 1875-1914 (London: Abacus, 1994), 178-179. 
that represented the leading technologies of their own time. The campus concept was one of the models of this kind of specialized university landscape.

\section{CONVERSATIONS WITH CITIZENS}

By the 1990s, the restructuring of industries had begun to influence major economic, societal, cultural and political transformations in Europe. The economic growth of the postwar years increased investments into scientific research that could be used to develop economically profitable or socially useful products. ${ }^{15}$ Information and communications technologies also opened possibilities for unforeseen activities and products.

The challenge to the universities was twofold. Internally, in terms of the disciplinary traditions, multidisciplinary approaches and new fields of study were needed for the new issues to be studied. Externally, in terms of the relationship to the society, the university had to respond to the growing interest of the society on the conditions of the research and on the social and ecological consequences of the technological innovations. ${ }^{16}$ From the history of laboratories and campuses built for the specialized functions of each discipline or field of study, the university needed to expand into new kinds of multidisciplinary activities and information systems with different spatial and urban requirements.

In the building program of the University of Helsinki, the challenges of the future made alterations to the earlier forms important. The Viikki campus area that had been built to become an 'academic village' for the Faculty of Forestry and Agriculture, was redeveloped as a high-quality suburb to which the University and its activities gave a distinct and valued identity. The multidisciplinary Biocenter brought together not only the University, various research and state institutions, and private companies in related fields, but also an ecological residential area

15 Eric Hobsbawm, Age of Extremes. The Short Twentieth Century 1914-1991 (London: Abacus, 1994), 263-270.

16 Ibidem, 551-557. 
with its public and commercial services. ${ }^{17}$ Similarly in medicine, the Meilahti campus was developed as a compact multidisciplinary area with the University Hospital, its research, teaching and care, adjacent to the emergency hospital of the city. Today Meilahti is no longer a separate campus but an integrated part of the city. The high quality of these areas has attracted researchers, students, residents, public institutions, companies, and international investments.

The programs for the areas were results of new forms of cooperation between the University and the City of Helsinki. The political changes around 1990 in Europe had opened new opportunities for cities as more independent agencies, beyond the frame of the nation-state. The competitors of Helsinki were defined as other big cities in the Baltic area such as Stockholm, Tallinn and Copenhagen, with the character of the city among the criteria of quality. Thus during the last 25 years, the dialogues of the university have been with the citizens and city of Helsinki, that is, the people, institutions and companies that form the urban culture of Helsinki. The city has developed new ways to integrate the university activities into those produced by other agencies to generate a living urban community. This has been an important and complicated process.

In 1990 on the $350^{\text {th }}$ anniversary of the University of Helsinki, the academic community discussed the more active use of the University milieu. The plans for the institutions in the city center involved new uses for some of the old buildings as well as the introduction of activity pockets within blocks and passages through buildings. ${ }^{18}$ The long history of the University has been refreshed in the historical heart of Helsinki. Much of the plans have been realized. The former University Hospital - earlier military hospital - was converted in 1999 as Topelia for the Department of History and Culture. A novel function, a study center with internet facilities and long access hours for students, Aleksandria, was built inside the block without any change to the street facades. The new university main library, opened in 2014, was constructed adjacent to it on the

17 Kervanto Nevanlinna, 'Voimat jotka rakensivat Helsinkiä 1945-2010', 354-357.

18 Eea Pekkala-Koskela, 'Keskustan yliopistokorttelit' ('The University quarter of the city centre'), Yliopiston Helsinki / University Architecture in Helsinki, ed. by Eea Pekkala-Koskela (Helsinki: Helsingin yliopisto, 1989), 174-179. 
site of a former department store and its parking levels, partially reusing its existing structural frame.

The buildings and urban spaces of the University of Helsinki both in the suburbs and in the heart of historical Helsinki are today, more than earlier, an integrated part of the city, its urban culture and vistas. In this, the university landscape can be seen as a revitalized reference to Enlightenment. The contemporary built forms of the university continue to carry the ideal of knowledge, open to the wider public, to be discussed and debated in the public sphere. It is the landscape of history but also the landscape of today and of the future, a landscape increasingly shared by the whole urban community. Throughout its history, the university landscape has not only sustained the continuity of interaction within the urban society, but also, through active dialogue with different parties, generated new perspectives for the future.

Anja Kervanto Nevanlinna: Universities in Urban History: The University of Helsinki as a Landscape of Dialogue

Keywords: University of Helsinki; urban architecture; UNIVERSity landscape; Enlightenment; Carl Ludvig Engel; Gustaf Nyström; COMMUNICATION; URBAN HISTORY

Anja Kervanto Nevanlinna is Senior Research Fellow and Adjunct Professor at the University of Helsinki. Her research has focused on European urban history during industrial and post-industrial eras, cultural history, architectural history and the history of cultural heritage. She received her PhD in 1997 on the topic Interpreting Nairobi. The Cultural Study of Built Forms. Her monographs include Voimat jotka rakensivat Helsinkiä 1945-2010 (Forces that built Helsinki, 1945-2010), vol. 4, History of Helsinki from 1945, History Committee of the City of Helsinki (2012 in Finnish, 2014 in Swedish); Kadonneen kaupungin 
jäljillä. Teollisuusyhteiskunnan muutoksia Helsingin historiallisessa sydämessä (Tracing the lost city. The industrial transformation of the historical heart of Helsinki) (2002); Interpreting Nairobi. The Cultural Study of Built Forms (1996). She was Principal Investigator for the Nordic-Baltic Research Project Industry and Modernism. Companies, Architecture, and Identity in the Nordic and Baltic Countries during the High-Industrial Period (2003-2007) and has published essays on urban history and an architectural encyclopedia for the general public (with Arne Nevanlinna, 2001). She is permanent member of the Finnish Society of Sciences and Letters. Her current research relates to architectural and urban preservation as political history. 